But an effective campaign will need to be more personal, more clearly targeted and more frank in its approach to change behaviour promoting the spread of AIDS. Although money spent by Ogilvy and Mather will reach a lot of people, there is an urgent need to match these funds with equal or greater sums spent on programmes in urban areas to reach drug users, the likely gateway for the virus to enter the general population. Whatever moral repugnance the administration may feel at dealing with drug abusers, the United States will neglect this group at its peril.

\section{Flirting with destruction}

\section{Mr Amadou M'bow as director-general for a third term is a recipe to put UNESCO out of business.}

INSTITUTIONS which the gods would destroy they first make irresolute. That seems to be the principle on which UNESCO, the United Nations Education and Scientific and Cultural Organization) is now courting extinction. The circumstances are these. The director general for the past ten years, Mr Amadou M'bow, is due to retire at the end of the year. For several months, UNESCO has been seeking a replacement. Perhaps to its executive committee's surprise, there have been several candidates, many of them well qualified for the job. One, for example, is professor Abdus Salem, awarded a Nobel prize for his contribution to the synthesis of electromagnetic and weak nuclear interactions and now director of the National Institute for Theoretical Physics at Trieste. With such candidates willing to shoulder the herculean task of putting UNESCO back on a solid foundation, it is beyond belief that UNESCO's managers should have such difficulty in making a suitable choice, yet, now, the word is that the executive committee cannot make up its mind, and that M'bow may be given a third term.

That will be a recipe for UNESCO's end. M'bow is a controversial character who is largely and personally responsible for the defection of three of UNESCO's members in the past two years - the United States, the United Kingdom and Singapore, in that order. The reasons are several and complicated. M'bow's first term in office was marked by a long dispute about the rights and wrongs of the infamous "world information order", designed as a scheme for improving the flow of information within the shrinking world that would also have had the effect of enabling governments to regulate the flow of information about themselves. The scheme was a legitimate topic for UNESCO's interest, but it was foolish of M'bow to have persisted with it when it had become clear that the scheme offended against western principles of what constitutes a free press. (It would be interesting to know where the Soviet Union, one of M'bow's supporters in that argument, now stands, with glastnost in the air.)

This is not the only complaint against M'bow during his two terms of office. The administration of his sprawling organization, never good, is at a lower ebb than ever. The proportion of UNESCO's shrunken budget spent on its own staff is greater even than it was. There is probably also some truth in the complaints that M'bow's way of doing business has led him to keep his staff enthralled by unjust exploitation of the need to employ people on short-term contracts. Arguments on these questions will persist, but they have no bearing on whether M'bow should be reappointed. The simple truth is that the departed members of UNESCO will not return while he remains in office and that his continued presence will probably drive others away. The African governments that support him may consider that a scandal, but it is the reality to which they have to adapt if they wish to keep UNESCO in being. It would be especially absurd that M'bow should be reappointed when there are alternative candidates whose reputation has not been tarnished by the troubles of the past few years.

\section{The art of the soluble}

Peter Medawar should be remembered as much as a writer as for his contributions to immunology

Following his death last week, at the age of 72 , much will rightly be made of Sir Peter Medawar's fundamental contributions to the science of immunology, of which the most important was the demonstration that the ability of the immune system to distinguish 'self' from 'non-self' is not inherent but is learnt during the system's development as a result of exposure to 'self' molecules. But for both those who intend to, and those that already, toil at the bench or in scientific committees, Peter Medawar's words of wisdom and advice are of equal importance. Fortunately, they are preserved in his extensive writings. Even more fortunately, Medawar was unequalled as a writer among scientists.

It was The Ait of the Soluble. published 20 years ago, that brought Medawar's skills as an essayist to the scientific community and beyond. The title of the book followed the lead of Bismarck and Cavour, who had explained the art of politics as "the art of the possible". Later, Medawar was to complain that his description of the art of the research as that of the art of the soluble had been almost wilfully misunderstood by some people to mean that he had advocated the study of easy problems yielding quick solutions, adding, in typical style, "unlike my critics, who were studying problems of which the main attraction (to them) was that they could not be solved".

Medawar's point was that science proceeds best when experiments test well-formulated ideas. "Clearly", he wrote, "a hypothesis so permissive as to accommodate any phenomenon tells us precisely nothing; the more phenomena it prohibits, the more informative it is." His extensive writing on the scientific process - of how "no new truth will declare itself from inside a heap of facts" - owed much to Karl Popper. Medawar was the first to acknowledge this; but he was also the first to enable those scientists with the nous to realize that process matters, but not the stomach for philosophers' academic writings, to appreciate what Popper has to say in a context that strikes a chord.

In his Advice to a Young Scientist (Harper and Row, 1979), Medawar returned to this theme: "It is a common failing - and one that I have suffered from - to fall in love with a hypothesis and to be unwilling to take no for an answer. A love affair with a pet hypothesis can waste years of precious time. There is very often no finally decisive yes, though quite often there can be a decisive no .... a scientist does not very often speak with complete confidence of proof. The more experienced he is, the less likely he is to do so". Such views were naturally linked to another of Medawar's favourite themes - the ways in which scientific papers obscure the scientific process. The conventions and constraints of the primary paper, he emphasized, allow little if any mention of the false trails, errors, serendipity and failed hypotheses that inevitably litter the pathway along which any successful scientist must tread. Is the Scientific Paper a Fraud? asks one of his most famous essays.

In his advice to the (potential) young scientist, Medawar repeats his favourite intelligence test: "To many eyes, some of the figures (particularly the holy ones) of El Greco's paintings seem unnaturally tall and thin. An opthalmologist who shall be nameless surmised that they were drawn so because El Greco suffered a defect of vision that made him see people that way, and as he saw them, so he would necessarily draw them. Can such an interpretation be valid?" As a rider, and one that captures much of the quality of the man and his writing, Medawar adds, "Anyone who can see instantly that this explanation is nonsense and is nonsense for philosophic rather than aesthetic reasons is undoubtedly bright. On the other hand, anyone who still can't see it is nonsense even when its nonsensicality is explained must be rather dull." Rereading Medawar periodically will keep dullness at bay. 